\section{Interferenz, analytische}

C. Vidal ${ }^{1}$ und W.-R. Külpmann ${ }^{2}$

${ }^{1}$ Landeskriminalamt Niedersachsen, Dezernat 53 „Chemie“, Hannover, Deutschland

${ }^{2}$ Hannover, Deutschland

Englischer Begriff analytical interference
Definition Systematischer Messfehler, der durch eine Einflussgröße hervorgerufen wird, die selbst kein Signal im Messsystem auslöst, jedoch zur Erhöhung oder Verringerung des erhaltenen Wertes führt.

\section{Literatur}

Darstellung von Referenzmessverfahren (1999) DIN EN 12286. BeuthVerlag, Berlin 